\title{
HOW SOCIALIST IS SOLIDARISTIC SOCIAL POLICY? \\ SWEDISH POSTWAR REFORM AS A CASE IN POINT
}

Summary: The postwar welfare state, as epitomized by Beveridge's Plan, seemed to mark a major departure from social policy's traditional Bismarckian ambition to ameliorate and preserve existing social circumstances. Many have found the reason for this turnabout in the power that parties of the Left achieved in the immediate postwar years, in Britain and especially in Scandinavia where reform was most pronounced. The article questions this political pedigree by examining the origins of postwar reforms, in this case in Sweden, in the ambitions and interests of the bourgeois parties and by analyzing the initial reluctance of the Social Democrats to follow the new reforming initiatives coming from the parties of the middle classes.

To contemporaries, the Second World War seemed to mark a turning point. ${ }^{*}$ At the very moment things looked blackest, a new vision of a better world was proferred. Roosevelt's formulation of "new freedoms", enshrined at first in the Atlantic Charter, indicated the general direction. Beveridge's plan for all-embracing, egalitarian social security, published to great public acclamation in 1942, heralded a more specific formulation of a new social compact. All were to be treated equally, not just in the formal sense of legal and political rights, but also in terms of their social rights. The sense of national community inspired by the common wartime deprivations was to continue into the peace. In the first flush of reforms following the end of hostilities, the promise of major change appeared to have been sincere. The Attlee government curtailed Beveridge's most farreaching ambitions, but still justified the hopes that had been invested in them. According to the most optimistic, Britain had peacefully undergone a Socialist revolution. ${ }^{1}$

* This is part of a larger study entitled The Politics of Social Solidarity and the Bourgeois Origins of the European Welfare State, 1875-1975 that also covers Britain, France, Germany and Denmark. The themes of the introduction and conclusion here are pitched at a level that reflects the material to be included there on Britain and Denmark as well as Sweden and may on occasion strain the ability of the Swedish case alone to bear them. I can only plead for patience until the empirical supply lines have been laid to the larger work. I am indebted to the American-Scandinavian Foundation for the resources to carry out the research for this article.

${ }^{1}$ C.A.R. Crosland, "The Transition from Capitalism", and R.H.S. Crossman, "Towards a Philosophy of Socialism", in Crossman et al., New Fabian Essays (London, 1952), pp. 25, 60. Retrospective reevaluations in Anthony Crosland, "Socialism Now", in his Socialism Now 
Similar reforms that had been prepared during the war in Scandinavia, Sweden especially, confirmed this tendency towards an egalitarian, universalist, solidaristic form of social policy as the expression of a new sense of national community. So did similar attempts at reform in France and Germany.

This new sense of community was most clearly and concretely embodied in the idea of social security. Although the concept had originated and first caught on outside of Europe - in New Zealand, in the New Deal - it was in the old world that it was to have the most dramatic impact. ${ }^{2}$ Postwar social policy was formulated under the spell of universalist, comprehensive, egalitarian social security. ${ }^{3}$ The ideal held up by reformers was for a system that would fuse all citizens and all risks to which they were heir in a single structure, treating all, regardless of distinctions of class, fate or biology, equally according to their needs. Kindled by the Atlantic Charter, resolved at the ILO's 1944 Philadelphia congress, formulated in the Beveridge, the Marsh, the Wagner-Murray-Dingell, the van Acker, the van Rhijn, the Parodi-Laroque-Croizat, the D'Aragona and other plans and proclaimed in the UN's Universal Declaration of Human Rights in 1948, the concept of comprehensive social security was to guarantee the new positive freedoms hailed by Roosevelt, was to embody a global New Deal promising freedom from want and completing the long course of human liberation by freeing man economically and socially. ${ }^{4}$ Social security was to social insurance what Bevin was to Bismarck. It realized the new sense of national community in terms of social policy, it modernized Liberalism, moderated Socialism. It aimed not to fulfill a social revolution, but also not to stabilize an unfair status quo. It was to create basic conditions of social equality, a minimum degree of security that defined the limits to which inequities would be

and Other Essays (London, 1974) and Crossman, "The Lessons of 1945", in his Planning for Freedom (London, 1965).

2 Miguel Garcia Cruz, "The Concept of Social Security in American Countries", Bulletin of the ISSA, IV, 6 (June 1951).

${ }^{3}$ On the concept of social security: Felix Schmid, Sozialrecht und Recht der sozialen Sicherheit: Die Begriffsbildung in Deutschland, Frankreich und der Schweiz (Berlin, 1981), pp. 43-52; Hans Günter Hockerts, "Die Entwicklung vom Zweiten Weltkrieg bis zur Gegenwart", in Peter A. Köhler and Hans F. Zacher (eds), Beiträge zu Geschichte und aktueller Situation der Sozialversicherung (Berlin, 1983), pp. 141-47; Franz-Xaver Kaufmann, Sicherheit als soziologisches und sozialpolitisches Problem: Untersuchungen zu einer Wertidee hochdifferenzierter Gesellschaften (Stuttgart, 1970), ch. 3. On the history and various uses of the term "welfare state", A.M. Donner, Over de term "Welvaartsstaat (Amsterdam, 1957); Stein Kuhnle, Velferdsstatens utvikling (Bergen, 1983), pp. 21-31, and, for France, Appendix 1 in Pierre Rosanvallon, La crise de l'état providence (Paris, 1981).

${ }^{4}$ Georges Gurvitch, The Bill of Social Rights (New York, 1946); Pierre Laroque in Notes documentaires et études, 450 (25 October 1946). See the magisterial analysis of the worldhistorical significance of the welfare state in François Ewald, L'état providence (Paris, 1986), especially pp. 395-405. 
tolerated. It was to make freedom fair by avoiding the worst consequences of the liberal social order, securing its best.

T.H. Marshall held his landmark Cambridge lectures to explain what had taken place in terms of political theory. Social rights had been given the same status as political and civil rights. The concept of full citizenship had finally been achieved. Beveridge's wife Janet caught the same idea in somewhat less abstract terms. "Whether you like it or not," she announced to her contemporaries, "whether you are glad or sorry, the Beveridge Report was the inauguration of a new relation within the state of man to man and of man to the state, not only in this country, but throughout the world. The ethic of the universal brotherhood of man was here enshrined in a plan to be carried out by every individual member of the community on his own behalf and on behalf of his fellows." retrospect, had been able to embody a new social consensus expressed through social policy. Solidarity limited to certain groups, as exemplified in the old form of social insurance, gave way to a general notion of solidarity transcending the limits of class. Egalitarian, unified, making identical demands of all, Beveridge's Plan marked the attempt to realize an authentic form of national solidarity. ${ }^{6}$

This extension and remodelling of social policy in the immediate postwar period marked a major change in the nature of the welfare state. If Napoleon III and his even cleverer pupil Bismarck had earlier been the guides, by 1945 social policy was prompted by a widespread consensus that welfare efforts should help the needy by treating all equally. Poverty and need were not to be reasons for exclusion from full membership in the community. Measures were therefore to be universalist in their embrace, egalitarian in their approach and redistributive in their effect. 1945 marked a new beginning in welfare policy. Earlier, social policy had been either the fruit of the elites' hopes for social stability, the need to preserve the capitalist system, or, at best, the outcome of a hard-fought battle between workers and the bourgeoisie. After 1945, however, all social and political groups agreed that social policy was not only necessary, but desirable. The architects of the British welfare state were Butler, Beveridge and Bevan, a Conservative, a Liberal and a Socialist. The gradual convergence of social policy among industrialized democracies that had been evident already before the war, now became one of the welfare state's most prominent characteristics. All nations, regardless of the political persuasion of their governments, became full-fledged welfare states after the war on the flow of this consensus.

\footnotetext{
5 Janet Beveridge, Beveridge and his Plan (London, 1954), pp. 7, 168. A more "organic" concept of the state, whatever that may mean, according to some: R.C. Birch, The Shaping of the Welfare State (London, 1974), p. 52.

${ }^{6}$ Guy Perrin, "Pour une théorie sociologique de la Sécurité sociale dans les sociétés industrielles", Revue française de sociologie, VIII, 3 (July-September 1967), p. 313.
} 
Two slightly different, potentially contradictory, arguments have attempted to explain why it was that the war marked a break in the development of the welfare state. The first traces the victory of the working class and its political representatives in certain countries after the war. Postwar measures were a turning point in the history of social policy and evidence of the close association among the Left, the working class and a vision of reform wherein the interests of the poorest and those of society as a whole were, for once, resolved without contradiction. ${ }^{7}$ Beveridge may have been a Liberal, but Labour's victory in 1945 was what made implementation of his vision possible. ${ }^{8}$ Similarly, analogous reforms were made possible in Scandinavia by Socialist power that had been consolidated before the war, but which now reached full bloom. Conversely, it was the eventual defeat of the Left in both France and Germany in the first years after the war that explains, in this account, why equally egalitarian reforms failed there.

And yet, why was the painless implementation of Socialist goals possible? Labour's victory and Attlee's reforms in 1945 cemented the tie between the working class and the welfare state, but the general agreement on an extension of social policy weakened it at the same time. The Left may have done the pushing, but the door was already ajar, its hinges well-oiled in the other explanation advanced for the success of postwar reform. This focusses on the consensus that extended even into the Conservative camp where hcstility to an expansive welfare state had formerly been the rule. Tories and Liberals in Britain, Christian Democrats in France and Germany, Liberals and especially Conservatives in Sweden were all associated with social reform in a way that seemed best explained in terms of a general consensus brought about by the special circumstances of the war. War created the need for and made it easier afterwards to continue increased state intervention and the higher taxes necessary to pay for it. The British coalition government had already of necessity committed the postwar government to a significant role in the peacetime economy. ${ }^{9}$ The bombing raids' indiscriminate destruction that blighted Bloomsbury as thoroughly as Brixton prepared the ground psychologically for a wider sharing of risk

${ }^{7}$ That the predominance of workers in British society was the social cause of the success of postwar reforms is the argument of Wolfgang Abenroth, "Soziale Sicherheit nach dem zweiten Weltkrieg: Die sozialgeschichtlichen Ursachen der Extension der sozialen Sicherheit", in Frank Benseler (ed.), Festschrift zum achtzigsten Geburtstag von Georg Lukacs (Neuwied, 1965); Jean-Jacques Ribas, "Sécurité sociale et classes sociales in France", Droit social, XV, 7 (July-August 1952), p. 479; Perrin, "Théorie sociologique", p. 317.

${ }^{8}$ Most extreme: Beveridge and Attlee's reforms were the essence of Socialism and even the Conservatives in this period were Socialist without knowing or admitting it. Peter Calvocoressi, The British Experience 1945-75 (London, 1978), p. 37.

9 A.T. Peacock and J.V. Wiseman, The Growth of Public Expenditure in the United Kingdom (2nd ed., London, 1967); Henry Roseveare, The Treasury: The Evolution of a British Institution (London, 1969), p. 278. 
through social policy. ${ }^{10}$ In Britain, the wartime and postwar consensus was but the culmination of an agreement between moderate Socialists and reforming Liberals that had been gradually evolving since the 1930s at least. With Keynes and then Beveridge, the acceptability of intervention in the market to secure goals of equity and justice became a commonplace among Liberals that facilitated agreement with Labour. Even significant elements of the Conservative party were moved to accept a larger role for the state, either by neo-corporatist tendencies or by traditions of Tory paternalism. ${ }^{11}$ Marshall was only the latest exponent of a Liberal theory of citizenship in which all were entitled to a moral position of equality in society. ${ }^{12}$ In Sweden, Liberals had been moving steadily leftward in their embrace of a greater role for the state in economic life and in social policy, in their acceptance of the need to legislate for a more just society. ${ }^{13}$ Keynes and Beveridge were hailed as the great exemplars. ${ }^{14}$ Even Conservatives there developed eminently practical interests in new forms of statutory intervention in social policy.

Titmuss' argument on the effect of the war has had a long and welldeserved half life. It is certainly fruitful as far as it goes; the question remains how far this is. If motivated only by this psycho-political sense of community, how long would the bourgeois parties have been willing to accept reforms that otherwise contradicted their interests? ${ }^{15}$ What were the other motivations that prompted this apparent consensus? Cynics have suggested that the bourgeois parties supported or agreed to reform out of fear of social upheaval in the volatile postwar situation and that Bonapartist intentions continued to motivate reform. ${ }^{16}$ Political democracy was not

${ }^{10}$ Richard M. Titmuss, Problems of Social Policy (London, 1950), pp. 506-07; "War and Social Policy", in his Essays on 'The Welfare State' (2nd ed., London, 1963). Qualified support for Titmuss in José Harris, "Some Aspects of Social Policy in Britain during the Second World War", in W.J. Mommsen (ed.), The Emergence of the Welfare State in Britain and Germany (London, 1981), and Arthur Marwick, Class: Image and Reality in Britain, France and the USA since 1930 (New York, 1980), ch. 11. Restatement with a slightly different angle in Robert E. Goodin and John Dryzek, "Risk-Sharing and Social Justice: The Motivational Foundations of the Post-War Welfare State", in Goodin and Julian Le Grand (eds), Not Only the Poor: The Middle Classes and the Welfare State (London, 1987).

${ }_{11}$ On the first, Nigel Harris, Competition and the Corporate Society: British Conservatives, the State and Industry 1945-1964 (London, 1972), part II. On the second, John Selim Saloma III, "British Conservatism and the Welfare State: An Analysis of the Policy Process within the British Conservative Party", (PhD, Harvard, 1961), ch. 2.

12 Andrew Vincent and Raymond Plant, Philosophy, Politics and Citizenship: The Life and Thought of the British Idealists (Oxford, 1984); Bill Jordan, Freedom and the Welfare State (London, 1976), ch. 15; John Stevenson, British Society 1914-45 (London, 1984), pp. 322-29.

${ }_{13}$ An evolution detailed in Kent Zetterberg, Liberalism $i$ kris (Stockholm, 1975).

${ }_{14}$ Bertil Ohlins memoarer, 1940-1951 (Stockholm, 1975), pp. 79-80.

${ }^{15}$ Scepticism on Titmuss' thesis in Kevin Jefferys, "British Politics and Social Policy during the Second World War", Historical Journal, XXX, 1 (1987).

${ }^{16}$ Alva Myrdal, "Internationell och svensk socialpolitik", in Ett genombrott: Den svenska 
enough to preserve the security and stability of democratic society. Privileges would have to be lessened, equality expanded. Workers would have to be given a greater share of social goods, a greater sense of participation in the community were the system not to crumble. On the Continent, the elites had embraced Fascism rather than concede power. In Russia, workers had taken matters into their own hands. In the bourgeois democracies, the only alternative to Fascism or Communism was a new conception of democracy based on social, not just civil and political equality. ${ }^{17}$

It is not necessary to go this far to account for the interest on the Right as well as the Left for postwar social reform, but attention to the conservative or at least moderate nature of successful postwar reforms helps explain why the bourgeois parties could be convinced to join what consensus there was. Agreement on social policy was certainly easier to achieve than on potentially more radical sorts of issues. But at the same time, the moderate intent of social policy reform after the war was not new. This was an inherent characteristic of such reform at all times: at best it was still less radical than a demand for social revolution. The unusually strong interest of the Center and Right for welfare reform after the war cannot be satisfactorily explained in this way.

Postwar reforms aimed to embody a new sense of community, a new definition of social citizenship. Social policy was made universalist to include all citizens on equal footing regardless of their class or wealth. Not just workers or the poor needed help or should be included. Burdens were to be redistributed according to the ability to bear them, not in line with outmoded actuarial criteria. Postwar reforms are often seen as marking the point at which the solidaristic demands put forth by the Left on behalf of workers and the oppressed became universal, became the formulation of the potential need of each individual as a human for solidarity, not just the claim of one class for alms from another. Redistribution on behalf of the impoverished had earlier been the Left's platform. In the immediate postwar era, Socialist and Social Democratic parties with their new-found power were able to forge a broad consensus on the virtue and utility of solidaristic social policy. In Britain and Scandinavia where the Left was strongest, it was able to implement measures that bound together a coalition of workers and the middle classes, of the poor and the better-off in solidaristic social policy that gave the welfare state a more solid political foundation than it had in those countries where expansive social policy remained the concern of the poor alone, a matter that the bourgeois classes

socialpolitiken: Utvecklingslinjer och framtidsmål (Stockholm, 1944); Hans Achinger, Sozialer Sicherheit: Eine historisch-soziologische Untersuchung neuer Hilfsmethoden (Stuttgart, 1953), pp. 14-15.

${ }_{17}$ The theme of Harold J. Laski, Reflections on the Revolution of our Time (New York, 1943). 
and parties resisted. ${ }^{18}$ To the extent that social benefits were changed from handouts and charity to social rights analogous to their civil and political cousins, something to which all had a claim, the welfare state became legitimate and enjoyed broad support. ${ }^{19}$

In this view, its universality was a crucial feature of the Anglo-Scandinavian Social Democratic welfare state. ${ }^{20}$ Universalism (whether all citizens were included in social policy regardless of distinctions of class, income and status that separate them in society) was the fundamental issue at stake in the postwar wave of reform. Universalism implied equality of treatment despite social inequities. It promised to dissolve the stigma of measures limited to the poor. It allowed a reapportionment of burdens among groups differently favored by fortune's caprice. It created a common solidarity, giving to the affluent as well as the poor a stake in the welfare state. It symbolized the values of what was expected to be a new political era. It helped create an equality of status defined by a level below which the inequities of civil society would not be tolerated. These were among the aspects that made universalism the quintessential characteristic of victorious wartime reform in Britain and Scandinavia. By including all, not just the poor, in social measures, all stood to gain and all had an interest in expanding or at least maintaining such arrangements. The poor were no longer marginalized as the only group to need the state's aid. Social policy became institutionalized, was no longer residual. The potential for back-

${ }^{18}$ Walter Korpi, "Social Policy and Distributional Conflict in the Capitalist Democracies: A Preliminary Comparative Framework", West European Politics, III, 3 (October 1980), pp. 304-05 and The Democratic Class Struggle (London, 1983), ch. 9; Gösta Rehn, "The Wages of Success", in Stephen R. Graubard (ed.), Norden: The Passion for Equality (Oslo, 1986), p. 148; Gøsta Esping-Andersen, Politics Against Markets: The Social Democratic Road to Power (Princeton, 1985), pp. 30-36 and passim.

${ }^{19}$ Kathi V. Friedman, Legitimation of Social Rights and the Western Welfare State (Chapel Hill, 1981), pp. 5-24.

${ }^{20}$ On universalism as a key characteristic of the Social Democratic/Labour welfare state: In Scandinavia: Robert Erikson, et al. (eds), The Scandinavian Model: Welfare States and Welfare Research (Armonk, 1987), pp. vii-viii, 41-43; Korpi, "Social Policy and Distributional Conflict in the Capitalist Democracies", p. 303. In Britain: Arthur Marwick, Britain in the Century of Total War (Boston, 1968), p. 343 and British Society Since 1945 (London, 1982), pp. 50-51; Alan Sked and Chris Cook, Post-War Britain: A Political History (2nd ed., Harmondsworth, 1984), pp. 38-39; Eric Shragge, Pensions Policy in Britain: A Socialist Analysis (London, 1984), p. 42; Pat Thane, Foundations of the Welfare State (London, 1982), p. 267. In more general terms: Anne-Lise Seip, Om velferdsstatens framvekst (Oslo, 1981); Julia Parker, Social Policy and Citizenship (London, 1975), pp. 4-5, 9-15, 40-41, 61-62, 145; Jens Alber, Vom Armenhaus zum Wohlfahrtsstaat (Frankfurt, 1982), p. 48. The only recognition that I have found that universalism was far from being a working class or trade union demand is in Göran Therborn, "Neo-Marxist, Pluralist, Corporatist, Statist Theories and the Welfare State", in Ali Kazancigil (ed.), The State in Global Perspective (Paris, 1986), p. 224 and "The Working Class and the Welfare State", in Pauli Kettunen (ed.), Det nordiska i den nordiska arbetarrörelsen (Helsinki, 1986), p. 13. 
lash from those groups who only paid for and did not benefit from social policy was correspondingly lessened. ${ }^{21}$ The most expansive, stable and firmly-grounded welfare states were therefore those that gave as many as possible a stake in social policy. Such universality was the fruit of the Socialists' ability to translate the demands of the impoverished and oppressed into common interests shared by a majority of society. The success of the solidaristic, egalitarian welfare state in certain countries and its failure in others is therefore explained by varying fortunes of the parties of the Left in the immediate postwar period.

Such a view, however logical and appealing, does not stand up to historical scrutiny. The universality and apparent solidarity of some of the most conspicuous and celebrated postwar reforms were not the result of the Left's strength, but were due to the immediate and direct interests the bourgeois classes and their parties developed in such social policy. It was not the representatives of the poorest who cemented political support for solidaristic measures by including all, but the middle classes and other groups traditionally excluded from social policy who here saw their chance to be among the beneficiaries of the state's largesse. The universality of postwar measures in Britain and Scandinavia was the result of bourgeois desires not to be excluded. The reforms that were successful here were ones that in fact benefitted this class most. That in the long run broadening social policy's embrace also helped the poor by assuring widespread political support for at least certain aspects of the welfare state is an effect for which the Left cannot claim credit. The following sections illustrate these claims through an analysis of pension reform in Sweden during and immediately following the war.

Universalism in social policy meant including all members of society, whatever their social category or the urgency of their need, in the same arrangements for the equalization of social risk. How European welfare systems achieved this goal and what it, in fact, implied varied meaningfully among the countries concerned and depended on several factors. First among these was the manner in which social measures had initially been implemented. The extremes of the spectrum of possible developments were defined at one end by the Continental social insurance tradition and at the other by the assistance-like arrangements chosen in Scandinavia. Germany and later France had begun with legislation limited to certain classes and related to need only insofar as social group and social weakness coincided. In the Scandinavian countries, early measures had covered all social classes in theory, but only the poor within each. British developments hovered

${ }^{21}$ Sara A. Rosenberry, "Social Insurance, Distributive Criteria and the Welfare Backlash: A Comparative Analysis", British Journal of Political Science, XII, 4 (October 1982). A similar sort of analysis in Harold L. Wilensky, The Welfare State and Equality (Berkeley, 1975), pp. 37-42, 54-59. 
between these two poles. Beginning in 1908 with a tax-financed, universalist pension system on the Scandinavian model, Britain switched course in 1911 to follow Bismarck's example of contributory social insurance limited to the working class.

Postwar universalist reform, in this case as embodied in pension legislation, was therefore a goal arrived at by separate paths from at least two distinct starting points. In one form it involved expanding measures formerly limited to a single social group - generally manual workers - horizontally to include all others as well. Such lateral universalism was particularly important in postwar reforms on the Continent but scarcely an issue in Scandinavia. No specific social groups were here excluded. All were included by statutory arrangements for pensions, by voluntary ones for health insurance, to the extent that they were needy. In Great Britain, Beveridgean reforms involved an element of lateral universalism. The extent to which the British population was made up of wage earners, however, meant that while all were integrated by Beveridge, this in fact added relatively few to the rosters of social insurance members.

Universalism in Britain and Scandinavia meant primarily reform of another sort. Because all, or almost all, needy were included, universalism here involved a vertical movement that drew in those who had not formerly been the object of statutory social policy attention. Anglo-Scandinavian universalism in effect meant giving what had previously been reserved for the poor alone to the better-off as well. Vertically universalist reforms eliminated need as a condition for benefit by abolishing means tests and relaxing earnings rules so that benefit and an increasing amount of other resources were no longer incompatible. ${ }^{22}$

The arguments advanced for eliminating needs-testing were various. The considerations of administrative simplicity that invariably find their way into social policy discussion were not truant here. Socialists argued that integrating even the better-off would make it easier to raise the taxes required by this and other reforms. Many thought that extending benefits to all would diminish the stigma of measures aimed at the poor. The most important consideration, however, concerned the relationship between statutory, needs-based benefits and private, unconditional provision. As long as their stigma was not overwhelming, needs-based benefits were of the greatest help to the poorest. At the same time, accurate targeting limited the funds necessary for social purposes and kept the classes from which resources were taken happy. The great disadvantage of need as a condition of entitlement, however, lay in the discouraging effect it had on

22 The distinction between vertical and lateral universalism is not normally drawn, although there is a hint of the latter concept in Jean-Jacques Dupeyroux, Evolution et tendances des systemes de Sécurité sociale des pays membres des communautés européennes et de la GrandeBretagne (Luxemburg, 1966), pp. 160-61. 
self-help. Privately arranged provision diminished eligibility for needsbased benefits. Attempts to raise statutory pensions above a miserly minimum were therefore resented by those not classified as impoverished, not only because taxes to finance extra generosity had to be increased, but because the direct penalties, within the field of social provision itself, for self-help were sharpened. The more ample means-tested benefits became, the more painfully the unimpoverished felt their exclusion.

The introduction of vertical universalism in Anglo-Scandinavian pension policy after the war represented a significant change in the nature of social provision. Where the public's efforts had earlier been aimed at the poor alone and therefore infused with an aura of stigmatization, they were now to embrace all on equal terms. Social policy, it has been argued, thereby took the leap from aid for the indigent, marginal, unlucky and disfavored to the status of a civic right. This form of universalism was an important step in the development of social policy from what has been called its residual stage to that of its institutionalization, from its role as emergency relief - the ambulance behind the battlelines of capitalism - to a normal aspect of life in increasingly complex social circumstances where need and self-reliance could seldom be predicted with assurance and all might one day find themselves thrown on the public's mercy.

Reforms embodying this shift were the result of pressure from the Left and the working class only to a limited extent. Because vertical universalism involved blessing the unimpoverished with benefits formerly reserved for the needy, the politics of its introduction were quite different from social reforms that involved a degree of downward vertical redistribution. The groups traditionally the object of social efforts stood to gain only whatever satisfaction could be had from the knowledge that all now received the same benefits. Groups with a direct interest in vertical universalism were the middle classes whose ability and willingness to provide for themselves were undermined by their exclusion from statutory measures.

\section{Postwar Pension Reform in Sweden and the Myth of Scandinavian Solidarity}

It was in the 1930s that Sweden began to assume the status, in certain circles, of the ideal type of modern society, the herald of social developments and progress that other countries would eventually follow. The Stockholm Exhibition of 1930, in which the comforts and delights of a peacefully Socialist democracy were presented to the world, played a role for modern welfare society analogous to the Great London Exhibition for the industrial era. ${ }^{23}$ In terms of welfare policy, however, it was not until the Second World War that her exemplariness was recognized worldwide.

${ }^{23}$ On Sweden's career as an ideal type, Arne Ruth, "The Second New Nation: The Mythology of Modern Sweden", in Graubard, Norden. 
Having languished since the nineteenth century in the social policy shadows of her smaller brother, Denmark, Sweden made the most of the years she spent during the war in profitable neutrality. ${ }^{24}$ As the shine wore off Beveridgean reforms in Britain, Sweden gained stature as a model to look to in these respects, however hopeless the task for other countries of emulating the more unusual of Scandinavian characteristics may have been. The strongest initiative for postwar social reform came from the Social Welfare Committee (Socialvårdskommittén), appointed in 1938 with a sweeping mandate for change. Where Beveridge had worked for eighteen months, the Social Welfare Committee, in thorough Swedish bureaucratic fashion, sat for well over a decade, issuing reports on virtually all aspects of social policy. The legislation that eventually sprang from its recommendations helped catapult the country into the social policy vanguard. Even the prestige of Beveridge's reforms could not stem the hubris of Swedish reformers. Generous pensions, munificent family allowances, an auspicious system of worker's compensation and peerless health insurance, was the modest conclusion the Social Democratic Minister of Social Policy, Gustav Möller, drew from a survey of postwar reform. The only competition he could discern to the excellence surrounding him was to be found in far-off New Zealand and, only secondarily, in Britain..$^{25}$

One of the longest strides Sweden took on her way to becoming the ideal type of the welfare state was the triumph of egalitarian universalism as perhaps that feature most quintessentially characteristic of Scandinavian and Social Democratic social legislation. Because all social groups had been included in welfare measures already early in the twentieth century, reforms now aimed to include all, however well-off, treating them to the same flat-rate benefits. Health insurance played an important role in this respect, but pension reform came foremost. ${ }^{26}$ Although hailed as the death of the

${ }^{24}$ While Sweden had paid great attention to developments in Denmark from the nineteenth century through the 1930s, by the Second World War she had pulled ahead in social policy and Denmark no longer played an important role in the Swedish debate. Åke Elmér, "Danmark i den svenska folkpensionsdebatten", Festskrift til Frederik Zeuthen (Copenhagen, 1958), pp. 55-65.

${ }^{25}$ Gustav Möller, Från Fattighus-Sverige till Social-Sverige (Stockholm, 1948), p. 13. Impetus and inspiration from Britain played little role in Sweden. Claims for the broad influence of the Beveridge Plan in Scandinavia seem to be without foundation. Examples: H.G. Hockerts, "Die Entwicklung vom Zweiten Weltkrieg bis zur Gegenwart", in Peter A. Köhler and Hans F. Zacher (eds), Beiträge zu Geschichte und aktueller Situation der Sozialversicherung (Berlin, 1983); Dupeyroux, Evolution et tendances, pp. 160-61, "L'évolution des systèmes et la théorie générale de la sécurité sociale", Droit social, XXVIII, 2 (February 1966), p. 113. Norway, perhaps because of the exile government in London, may be the exception: Stein Kuhnle, Velferdsstatens utvikling: Norge i komparativt perspektiv (Bergen, 1983), p. 155.

${ }^{26}$ The standard work on the topic is Åke Elmér, Folkpensionering $i$ Sverige: Med särskild hänsyn till alderspensionering (Lund, 1960). A competent general narrative is in Rolf Broberg, Så formades tryggheten: Socialförsäkrings historia, $1946-1972$ (n.p., 1973). Broberg was se- 
poor relief concept, the 1946 law on national pensions ("folk pensions") was not as dramatic a change as the comparable Beveridge reforms. ${ }^{27}$ Unconditional, universal, largely flat-rate pensions had been introduced already in 1913, but at a level that was more symbolic than useful. To keep body and soul together, means-tested supplementation for the poor had also been granted. In 1937 the Socialist government had graded pension supplements according to geographical cost of living variations, despite protest from rural interests, in order to reduce means-testing for urban residents. Although raising the unconditional element of pensions significantly, the 1946 national pensions retained means tests for most of the supplements that bridged the gap between flat-rate benefits and individual needs.

The Social Welfare Committee proposed universal unconditional flatrate pensions, paid at a uniform rate throughout the country and raised to subsistence by means-tested supplements that took account of variations in the cost of living, family and personal circumstances. The Committee's main problem on pensions concerned the abolition of means testing and the vertical extension of benefits to all. It weighed, but did not chose between two primary alternatives. In one, an unconditional basic benefit of 600 crowns was topped by a means-tested pension supplement in addition to other sorts of supplements also subject to need. The second foresaw a wholly unconditional pension of 1000 crowns, along with the same targeted supplements as the first alternative. Both suggestions were calculated to give the poor identical benefits, while the latter was, of course, more generous to the better-off. What distinguished them was the importance attached to means testing in each. While the first, and most targeted, was backed by the majority of the Socialists and the Liberal representative in the Committee, the Agrarians and the Conservatives supported the second. The argument for the former alternative was that it made little sense to give equally large benefits to those who did and did not need them. A potpourri of considerations did duty for the other approach: that a heavily meanstested system which tempted pensioners to conceal their resources from the authorities was undesirable, that granting pensions to even the affluent would strengthen the entitlement by right that did not come as naturally to tax-financed measures as to contributory, that it was reasonable for the wealthy who bore the heaviest tax burden to enjoy the same benefits as others. ${ }^{28}$

The most important reason, to judge from the Committee's deliber-

cretary to the Social Welfare Committee and to the First Special Standing Committee in Parliament that dealt with the 1946 pension law.

27 The claim is in Karl J. Höjer, Svensk socialpolitisk historia (Stockholm, 1952), pp. 264-65.

28 Utredning och förslag angående lag om folkpensionering (SOU 1945:46), pp. 138-39. 
ations, for abolishing means tests for pensions concerned the relation between statutory and private provision against social risk. ${ }^{29}$ Since pensions were to be raised to approximate subsistence, the level of means-testing within the pension system itself threatened to undermine the willingness of individuals to make provision for themselves and employers for their workers. The more generous means-tested benefits, the greater the disincentive for private measures. Social policy, the Committee's Social Democratic chairman, Bernhard Eriksson argued, ought to be based on the duty of self-help. Statutory measures should encourage, not impede, individual voluntary arrangements. For this, a system of social policy based significantly on a personal test of need was of little help. ${ }^{30}$

\section{Conservatives and Social Reform}

All Swedish parties were prompted during the war to take a greater interest in social policy. The Conservatives especially decided to abandon their former views on the matter and came to embrace a definition of social policy that made it a matter of concern and interest to the middle classes. Already in 1943, the party's vice-chairman, Fritjof Domö, argued that social policy could be formulated in terms acceptable to Conservatives and urged the party to begin a reconsideration of its stance for the upcoming elections. ${ }^{31}$ The Conservative election platform was a response to the Social Democrats' radical new program for the postwar period. On social policy, the party advocated measures to help counteract the nation's declining fertility and to stem urban growth by improving conditions in the countryside. Social insurance built on the individual's responsibility was seen as the way to expand other welfare measures. Many favored a clearer formulation in the program of the party's concern for the middle classes. ${ }^{32}$

When the 1944 elections went badly for the bourgeois camp, the Conservatives set in motion a change of leadership and renovated their ideology. ${ }^{33}$ A quarter century had passed since the last formulation of a program, while both the Socialists and Liberals had reformulated their positions in tune with recent developments. Significant social changes since the last program that required attention, the party noted, included crisis conditions in agri-

${ }^{29}$ Riksarkivet [hereafter RA], Stockholm, 1185/3, Socialvårdskommittén [hereafter SVK] minutes, 2 October 1944, Eriksson, Östlind, Höjer.

${ }^{30}$ Bernhard Eriksson, Vår framtida socialvård (Stockholm, 1943), pp. 5-6.

31 RA, Moderata Samlingspartiets Deposition, AII:1, Representantskapet, minutes, 1 November 1943 and Bilag 5.

32 RA, Moderata, AI:2, Högerns Riksstämma, minutes, 16 June 1944, Sjöquist and Arrhén; minutes, 17 June 1944, Stjernlöf, Magnusson, Bagge; "Programuttalande".

${ }_{33}$ Background in Elisabeth Sandlund, Svenska Dagbladets historia (n.p., 1984), vol. III, pp. 126-28, 204-07. 
culture, the increasing importance of intermediary organizations and the growing role of white collar employees. A modern Conservative party might now be able to win significant support among wage earners. ${ }^{34}$ The Conservatives' interest in an active social policy went beyond hopes of attracting wage earners to embrace a new solicitude for the party's traditional constituency expressed in terms of statutory intervention. Welfare benefits ought to be justly distributed, Domö told Stockholm's Conservative Club in 1945, adumbrating what was to become a leitmotiv of the party's social policy. The middle classes shouldered society's heaviest burdens and had justified demands not to be ignored by the welfare system. To meet them was the duty of the bourgeois parties. ${ }^{35}$

The new program was presented in 1946 as the Swedish equivalent of the Beveridge Plan. ${ }^{36}$ It illustrated the Conservatives' ability to make social policy their own, particularly the way they were able to tailor measures to suit and benefit the middle classes. A correctly crafted social policy, in the program's view, was a worthwhile social investment. Sweden's demographic problems and the flight from rural to urban areas could be helped through housing and family policies. Labor mobility could be enhanced by pension reform. Preventative and rehabilitative measures were economically beneficial in the long run, although expensive in the short. Social policy helped secure a tranquil labor market and a more productive and contented working class. With broad support for their new social policy line, Conservatives would have a much stronger platform from which to defend the virtues of a market economy and individual property rights. No longer - so Jarl Hjalmarsson, now head of the committee that had formulated the new program and soon to be party chairman, reasoned - would their opponents be able to argue that a free economy was without security for the individual. ${ }^{37}$

However, social policy should neither be bought at the expense of the middle classes, nor exclude them. It was not to be a means of income equalization or a one-sided class-specific arrangement. ${ }^{38}$ The middle classes

${ }^{34}$ RA, Moderata, AIV:2, Överstyrelsen, minutes, 8 December 1944, Bilag 2, Motion no. 2. RA, Moderata, Partiledarna, Fritjof Domö/4, ms. for speech, 9 December 1944.

${ }_{35}$ RA, Moderata, Partilederna, Domö/5, ms. of a speech to Högernklubben, Stockholm, 3 October 1945.

${ }^{36}$ RA, Igor Holmstedts Samling om Högerpartiet, 2, "Mål och medel inom socialpolitiken: En diskussionspromemoria".

${ }^{37}$ RA, Moderata, AI:3, Högerns extra Riksstämma, 1-2 February 1946, Hjalmarsson's speech, appended to the minutes.

38 RA, Holmstedts Samling, 1, Högerns Programkommitté, preliminary draft of the program, Section 8. The manuscripts in Holmstedts Samling are the sources for the commentary to the new Conservative program published by the party: Högerns Riksorganisation, Frihet och framsteg: Kommentar till Högerns handlingsprogram (Stockholm, 1946), especially pp. 110202. In the social policy part of this, the party advocated a universal, compulsory health 
were to be included. Many who fell into this category were not well-off and stood to benefit from the equalization inherent in social policy. Others would profit from those aspects (family allowances, for example) that redistributed funds within income classes. In concrete terms, it was concluded, the question of including the middle classes hinged on the role of means tests in social policy. ${ }^{39}$ Means tests, in the Conservative view, were not just a practical matter, a disincentive to savings and continued work for those who thereby lost the right to social benefits. They touched on more fundamental questions of a just distribution of social benefits among all regardless of wealth, on the issue of democracy itself. The larger benefits were and the greater the number of citizens receiving them, the more pressing the reason to eliminate means testing. Otherwise an unjustified and undemocratic distinction would be created between citizens who were "favoritized" and those who were placed beyond society's social concern: a neat reversal in Conservative ideology of traditional views of self-reliance and dependence. Eliminating means tests was an expression of "humane communism" that rectified obvious injustices inherent in the distribution of social benefits to the poor alone. ${ }^{40}$ "Why should one not see society as an organization for equalizing risks," Hjalmarsson wondered, "and for the provision of minimum standards of security not only for those who are badly off, but also for the industrious?"41

When the draft program was discussed within the party, many feared that such radicalization might alienate the party's traditional constituency. A majority, however, strongly influenced by the party's youth organizations, insisted that such attention to middle class interests was necessary. At the moment, one noted, the middle classes received few of the state's benefits. For this reason, means tests in social policy had to go. ${ }^{42}$ Social policy, the program finally adopted announced, is an expression of social solidarity

insurance, universal national pensions without means tests, a reformed system of public assistance, now to be called social assistance rather than poor relief, and extension of accident insurance to the self-employed.

${ }^{39}$ RA, Holmstedts Samling, 2, "Mål och medel inom socialpolitiken".

${ }^{40}$ For example, that someone who had saved up a small sum of capital had to use this to pay the expenses of his retirement home while those who had nothing received this gratis from the state. RA, Holmstedts Samling, 2, P.Hj. Fagerholm, "Några synpunkter på inkomst- och behovsprövning inom socialvården."

${ }^{41}$ RA, Moderata, AI:3, Högerns extra Riksstämma, 1-2 February 1946, Hjalmarsson's speech, appended to the minutes.

${ }^{42}$ The two issues over which means tests were being discussed at the time were pensions and school meals. The party was unanimous about eliminating them for pensions (by far the more important of the two), but only radicals pressed the second issue as well. RA, Moderata, AIV:2, Överstyrelsen, minutes, 31 January 1946, Järte, Wistrand, Falla, Nylander, Ohlsson, Hjalmarsson; AI:3, Högerns extra Riksstämma, minutes, 1-2 February 1946, Högerns Riksstämma, minutes, 17-18 June 1946. 
and a necessary complement to the free market. It was the broad middle strata that now needed attention. Their members had borne the heaviest burdens, but received only the most meager benefits. These circumstances ought to be taken into account in economic and fiscal, but above all in social policy. ${ }^{43}$

\section{Socialists and Universalism}

The bourgeois camp advocated enhanced and expanded social policy, now extended also to the middle classes, and abandoned attitudes traditionally commonplace on this side of the political spectrum where statutory intervention in such matters had usually been accepted only as a means of last resort, circumscribed and stigmatized to limit its cost. It did so in a manner that appealed to Conservative ideological desires to strengthen the family and preserve the race, as well as directly to the material instincts of the party's middle-class constituency. ${ }^{44}$ Among the Conservatives, this was a dramatic change. The political advantages of direct aid in this fashion to middle-class groups suffering the effects of war and modern economic development was one motive. The irreconcilability of means-tested social policy that went beyond an absolute minimum with individual initiative and self-help was another. Were welfare measures to be expanded to cover more than the most indigent in any but the most miserly fashion, then all had to be included. From a concern for the poorest only, social policy began to change into an issue for the broad middle strata and therefore for the bourgeois parties that still alone tilled their most fertile political soil here.

For the Socialists, on the other hand, the matter was more complicated. The immediate postwar period was a turning point for the party in the development of its self-conception. The decline of agrarian groups, where Social Democrats had long harvested support, was a fact of demographic and political life. The proportional shrinkage of blue collar workers and the growth of white collar employees, suspended socially somewhere between the working and the middle classes, was slowly becoming apparent. So was the gradual increase in affluence for all classes that promised to leave the misery and impoverishment of the Kampfzeit of the 1930s but a rhetorical allusion in the speeches of the party elders. Pensions presented one of the first issues through which the Socialists began to shift from being a party concerned primarily with the interests of the impoverished to one that had

${ }^{43}$ Quoted in Dag W. Scharp (ed.), Frihet och framsteg: En krönika om Högerpartiet (Nyköping, 1959), p. 452. A copy of the program is in RA, Moderata, AI:3.

${ }_{44}$ E.g. Frihet och framsteg, p. 112. There is a continuity here with family policy reform in the 1930 s that also appealed to eugenic and natalist concerns on all sides of the political spectrum. Lisbeth Rausing, "The Population Question: The Debate of [sic] Family Welfare Reforms in Sweden, 1930-38”, Europäische Zeitschrift für Politische Ökonomie, II, 4 (1986). 
to deal both with a working class rapidly acquiring the attributes and attitudes of modest prosperity and with new classes that, although dependently employed, affected airs formerly the exclusive possession of the independent middle classes.

These were the long term developments that would eventually give Socialists the same interests as the bourgeois parties in tailoring social policy to the middle classes. In the short term, the shift in focus from alleviating misery to not impeding affluence, from impoverished workers to embourgeoisé social classes, was a much more wrenching one for the Socialists than it had been for the Conservatives and Liberals. Pension reform and the choice between universal measures even for the affluent and means-tested benefits limited to the poor was one of the main issues through which the Socialists worked out their new orientation. The bourgeois parties had obvious reasons to favor vertically universalist pensions. ${ }^{45}$ The identity of the groups that stood to gain most from unconditional benefits gave them a direct interest in addition to whatever tactical advantages they could reap from backing pension universalism. Socialists, on the other side, were presented with a dilemma: how to deal with generous, ideologically attractive, universal social policy that helped most those who needed it least.

At its congress in 1944, a motion was tabled that aimed to commit the party to universal, unconditional pensions. The current basic pensions were too low to keep many elderly off public assistance. They should be raised and stripped of their public-assistance-like traits, especially means testing. Were all to receive pensions, the movers reasoned, many would support such reform. ${ }^{46}$ The party executive could not agree how to respond. Gustav Möller, the party's Minister of Social Affairs, wanted to eliminate meanstesting and encourage employers to initiate occupational pension schemes for their wage earners. Eriksson, the Social Welfare Committee's Chairman, spoke for the party's rear guard in rejecting unconditional universal

${ }^{45}$ Were it not for the unexamined assumption that solidaristic social policy must have been the brainchild of Socialists, there would be no cause for the surprise sometimes expressed that the bourgeois parties, normally opposed to expensive social reform, seemed now to have turned coats to support the most extravagant of the proposals. Elmér, Folkpensionering, p. 85, for example, thinks the Right's attitude to these reforms the most difficult to explain. Similarly, Esping-Andersen's surprise that the bourgeois parties proved "amazingly willing to embrace universal, non-contributory plans whenever popular opinion seemed to favor them," is understandable only given his assumption that universalism was an especially Socialist goal. Politics Against Markets, p. 157. More sophisticated (or unconcerned?) is the approach that admits that the universalist pensions proposed were the handiwork of the bourgeois parties, but then goes on to describe national pensions as one of the pillars of Möller's and the SAP's social policy edifice. Stig Hadenius et al., Sverige efter 1900 (Stockholm, 1967), pp. 194-95). The only one to get matters right is Therborn, "The Working Class and the Welfare State", pp. 52-55.

${ }^{46}$ Sveriges Socialdemokratiska Arbetareparti [hereafter SAP], Protokoll, 1944, pp. 432-33. 
pensions as a waste of resources better used elsewhere. Occupational pensions he dismissed as a matter of interest mainly to well-paid workers beyond the party's immediate ken ${ }^{47}$ The executive's rejection of the motion was colored by considerations of social efficiency. The means tests for municipal supplementary pensions were less stigmatizing than those for public assistance, it argued. Were supplementary pensions universalized without regard to need, costs would be increased while the worst-off gained little. The goal of the party's social policy, however, was to help precisely the poorest. As a compromise, the earnings rules attached to means tests might be relaxed. Möller was less dismissive. He sympathized with the aim of abolishing means tests, but feared that it was politically unrealizable. Many opposed the idea of helping the affluent in this way. ${ }^{48}$

The labor movement's postwar political program, published in April 1944 , was - not surprisingly - less than unanimously exuberant on the issue. Not until point eleven did it mention pension reform, and then only to demand unspecified benefit increases and cheaper housing for pensioners. ${ }^{49}$ The interest the party was nevertheless able to muster shortly after this initial rejection was due to political pressure from the Center and Right. The low profile assumed by pension reform in the 1944 elections was determined largely by the party's inability to take an unambiguous position on the issue. Was it really a practical impossibility to formulate a position on pension reform for the elections, Finance Minister Wigforss exclaimed with what appears to have been frustration at a meeting of the party executive. A declaration of support for provisional benefit improvements, he proposed, anticipating accurately the position that expedience eventually dictated, would provide the party with a platform that sufficed. ${ }^{50}$ Socialist embarassment at the party's inability to take a clear stand on the issue was noted with Schadenfreude by others. ${ }^{51}$ Although the Socialist parliamentary group's majority eventually decided in favor of unconditional and universal pen-

47 Arbetarrörelsens Arkiv [hereafter ARA], SAP, Partistyrelsen, minutes, 16 January 1944.

48 SAP, Protokoll, 1944, pp. 435-37.

49 Arbetarrörelsens efterkrigsprogram (Stockholm, 1944). Nor was mention of national pensions made in the party's 1944 program, reprinted in Från Palm till Palme: Den svenska socialdemokratins program, 1882-1960 (Stockholm, 1972), pp. 160-68. The standard work on the subject interprets the Socialists' supposed disinterest in universalist pension reform as evidence that such changes were the result not of party-political pressure, but were occasioned by the Social Welfare Committee's proposals. Elmér, Folkpensionering, pp. 139-40. While true, the assumption that lies behind this analysis, that the SAP of course supported the reforms that eventually resulted and that the party's lack of initiative needs explaining, is not. The SAP had no reason to press for universalist reforms in 1944 that, first, had not yet been put forth in the Committee, and, second, had already been rejected within the party.

${ }^{50}$ ARA, SAP, Partistyrelsen, minutes, 23 April 1944.

${ }^{51}$ Bondeförbundets Medlemsblad, II (June 1946). RA, Bondeförbundet-Centerpartiets Arkiv, AI:4, Riksstämman, minutes, 30 June - 2 July 1946, Bilag 30, speech by Axel PehrssonBramstorp, 30 June 1946. 
sions, Wigforss noted in retrospect, the party's doubts and hesitations had helped its opponents. Conservatives insisted that the victorious line had first won their support and, as far as he could see, they were right. ${ }^{52}$

It was not until May 1945 when the unconditional, universalist alternative was presented and the Social Welfare Committee split, putting the choice in the government's hands, that the dilemma was posed in real political terms. Shifting the decision to the government forced the SAP to make up its divided mind. When the party executive met later in 1945, little progress had been made. Möller outlined the problems. The bourgeois parties supported the proposal to eliminate means-testing from the pension itself. Sympathies for the unconditional line were hard to resist. On the other hand, there were obvious arguments against it. Abolishing means tests would cost the state $10 \%$ more than the partially targeted alternative. If the government could offer these extra millions, it would be preferable to channel them to the poor. The non-means-tested alternative was administratively superior, but this alone was no reason to sacrifice the interests of the impoverished. Tage Erlander, soon to succeed Per Albin Hansson as Prime Minister, noted that the bourgeois parties wished to convey an impression of support for generous and humane welfare by abolishing means tests. Those groups least likely to favor abolishing means tests, among which the issue was not at all popular, he feared, were the Social Democrats' own voters. ${ }^{53}$

\section{The Road to Legislation}

When the results of the survey of opinion from interested parties that is an institutionalized part of the Swedish legislative process began to trickle in on the Social Welfare Committee's report during the winter of 1945/46, the political weathervanes all pointed in the same direction..$^{54}$ Generally, with few and only half-hearted exceptions, the vast majority of those organizations with a view on the matter preferred the unconditional line. Reasons for opposing means tests included administrative simplification, the encouragement their abolition would give to other forms of provision and to the elderly's willingness to continue working. A concern that those who had saved not be punished by having their pensions reduced led the Employers' Federation (SAF) to support the unconditional alternative, while its sense of social justice inspired the conclusion that highly paid wage earners who

${ }^{52}$ Ernst Wigforss, Minnen (Stockholm, 1950-54), vol. III, p. 304. Riksdagens Protokoll, AK 1948:31, 3 July 1948, p. 58. The Conservatives took full credit for universal pensions in their account of the matter, Högerns Riksorganisation, Politisk valhandbok, 1946, pp. 150-53. Also, Gösta Lindskog, Med Högern för Sveriges framtid (Stockholm, 1954), pp. 449-51.

${ }_{53}$ ARA, SAP, Partistyrelsen, minutes, 9 December 1945. Tage Erlander, 1940-1949 (Stockholm, 1973), pp. 147-48.

${ }^{54}$ Riksdagens Protokoll, Prop 1946:220, pp. 65-99. 
helped finance pensions through their taxes ought not be deprived of benefit. The interest that employers shared with the white collar wage earners' unions in occupational pension schemes also spoke for an end to targeting. Means tests discouraged occupational arrangements and other voluntary efforts proportionally to the benefits forfeited. Now that pensions were to be raised, employers pointed out, this unfortunate effect would be magnified. Occupational pension schemes for more modestly placed wage earners were certain to be reconsidered, they threatened, were statutory pensions not granted unconditionally. The white collar trade union umbrella organization, the TCO, favored abolishing means tests not only for the basic pension, but also for several of the supplements. Bereft unlike their white collared confreres - of any immediately obvious motives of pecuniary self-interest in unconditional pensions, workers organized in the blue collar union umbrella, the LO, added their voice to the chorus denouncing means tests for the demographic concerns that troubled others as well and for more etherial considerations of stigma and status. ${ }^{55} \mathrm{Un}$ conditional pensions gave money to the well-off, they admitted, but this might be acceptable if pensions were thereby regarded as the right of every citizen.

Difficulties of administering means tests in the countryside gave independent farmers a particular interest in unconditional benefits. Agriculture often blessed them with greater assets, on paper at least, than other social groups and the peculiarities of inheritance in the countryside frequently disbarred farmers from receipt of pension. The private insurance companies were delighted by the unconditional line that left them a fertile field to till with little competition from the state. The organs of the state bureaucracy were generally pleased by the administrative simplification it promised. While some saw no reason to retain premiums at all, preferring to found entitlement on the vaguer concept of a recompense from society for a life of productive toil, the trade unions insisted that they be kept.

Faced with this unanimous chorus in praise of universal benefits, those Socialists with reservations had little chance of prevailing. Social Minister Möller attempted to improve the means-tested line, but failed to his own satisfaction. Were it adopted, earnings rules would have to be relaxed in order to soften the penalties imposed on voluntary efforts, thus approximating in any case the effect of the unconditional line. ${ }^{56}$ The difference in costs between the two alternatives was thereby reduced. When the Social Welfare Committee concluded that the necessary funds could be collected

55 Demographers forecasted an ageing of the population in the postwar period and it was therefore considered important to encourage the elderly to continue working.

${ }^{56}$ Earnings rules determined the amount of benefit forfeited when the recipient had other means. 
by increased taxes, the balance tipped in favor of the unconditional line.$^{57}$ Personally, Möller was for abolishing means tests, but in the early spring of 1946 he was still willing to change had the parliamentary group so desired ${ }^{58}$ Several of his colleagues in the government, especially Prime Minister Per Albin Hansson, Finance Minister Wigforss and Erlander, disagreed. ${ }^{59}$ Their argument in favor of means tests had two prongs. First, it was the cheapest solution. Wigforss feared that the nation could not afford all the new expenses earmarked by the SAP's social policy program. The budget had to be balanced, he insisted, and the party ought not to assume a continued rise in national income. Second, it was the correct one in principle. The SAP's goal had always been to help the worst-off and for them means tests meant little. The main effect of their abolition was to give civil servants and those with other provision an additional 1000 crowns - a result, they feared, the electorate would not appreciate. On the other hand, Per Albin Hansson admitted, there would be political difficulties were the party to back means tests while the bourgeois flank lined up on the opposite side. Möller's view emerged victorious. A large majority of the parliamentary party supported the unconditional line, allowing him to formulate policy according to his instincts. ${ }^{60}$

Administrative, labor market and demographic arguments in favor of the unconditional alternative did duty yet again in his bill of April 1946, undergirding the more general concept of entitlement to benefits regardless of need. The indiscriminate distribution of pensions was somewhat restricted, however, by doubling the premium ceiling so that the funds collected approximately covered the benefits received by the most affluent.$^{61}$ Contributions were kept for the psychological sense of entitlement they fostered, to force also those exempt from taxes to pitch in, and finally because the sums realized in this manner were too significant to be ignored. ${ }^{62}$

In the bill's parliamentary treatment, general unanimity carried the day. All facets of the political constellation in the lower house hailed the bill as a major advance, the Communists welcoming the Conservatives in what they

${ }^{57}$ Riksdagens Protokoll, AK 1946:27, 20 June 1946, p. 5.

${ }^{58}$ His account in "Inkomstprövade pensioner?"' in Gustav Möller “Hågkomster", Arbetarrörelsens årsbok 1971, pp. 180-82.

${ }^{59}$ For Erlander, see also, ARA, Erlanders Arkiv, BI:7, ms. for speech, Kalmar and Nybro, 3 February 1946, pp. 2-4, ms, speech, Stockholm, 9 May 1946, "Barnkostnadernas fördelning", pp. 14-16.

${ }_{60}$ ARA, SAP, Riksdagsgruppen, minutes, 29 January 1946, 5 March 1946. ARA, Per Albin Hanssons Arkiv, 1b, Dagböcker och minnesanteckningar, 2 March 1946.

${ }^{61}$ This corresponded to the Conservatives' willingness to have flat-rate benefits financed by premiums related to the ability to pay, where the affluent paid in premiums approximately the value of their benefits. RA, Holmstedts Samling, 2, Högerns Programmkommitté, "Några synpunkter på inkomst - och behovsprövning inom socialvården", and "Social trygghet".

${ }^{62}$ Riksdagens Protokoll, Prop 1946:220, pp. 107-22: 1SäU 1946:1, p. 32. 
chose to interpret as their newly found support for social reform. There were many, Möller acknowledged, who thought it unreasonable for rich and poor alike to receive the same benefits. Although true, he admitted, the point of reform was not to give the wealthy a pension, but to allow others to continue working without penalty after the normal retirement age. Retaining a means test would have created unnecessary administrative complications and since, for the state's finances, the means test was of little consequence, it had made most sense to eliminate it altogether. S.A.A. Hagård, a Conservative member of the Social Welfare Committee, took up the same theme, wondering aloud whether it was not the equality he perceived in giving the same benefit to both landowner and laborer that had permitted strong political backing for such reform. Dissonant notes to this chorus of good will were sounded by those on the Left who supported traditional Socialist attempts to help the poorest first and therefore objected to this gift presented the well-off. The attitude of the Conservatives was especially interesting, one noted. They had never before supported the abolition of means tests. Perhaps pensions were now granted with such largesse that all social groups had an interest in receiving them. ${ }^{63}$

\section{Unanimous Reform, Disputed Financing}

The unconditional, universalist alternative struck political gold. Pension reform of this ilk was designed to gain the broadest political backing. In and of itself hurting no one while helping all, especially those groups traditionally hostile to generous social measures, universalism gave to the well-off what had formerly been reserved for the poor alone. Affluent groups, in particular urban residents, whether wage earners or independents, stood to gain most from the removal of means tests. ${ }^{64}$ Whether or not statutory

${ }^{63}$ Riksdagens Protokoll, AK 1946:27, 20 June 1946, pp. 3-41. Erlander was disconcerted that the Socialists were deprived of the tactical advantages of passing pensions against bourgeois opposition. ARA, Erlanders Arkiv, BI:8, ms. speech, Torsby et al., 7 July 1946; "Valföredrag 1946", pp. 5-6. The continuing ambivalence among Socialists over the virtues of abolishing means tests may be gauged by the manner in which the whole problem flared up once again within the party in 1948. Because national pensions were not cost of living indexed (Möller had feared lowering benefits in case prices fell), postwar inflation raised the necessity of cost supplements that were either to be means-tested or not. Against Socialist wishes, non-meanstested supplements won in 1950. Gustaf Jonasson, Per Edvin Sköld, 1946-1951 (Uppsala, 1976), pp. 57-61. "Dyrtidstilläggen", in Arbetarrörelsens årsbok 1971, pp. 187-89.

${ }^{64}$ The coincidence of wage earning and self-employed interests here was incorporated by Emil Liedstrand whose arguments advocating the abolition of means tests circulated among both of these groups. See Tjänstemannarörelsens Arkiv, Bergendal, 530/6, "Några erfarenheter rörande verkningarna av behovsprövningen inom socialförsäkringen", 31 August 1945. "Behovsprövning inom folkpensioneringen", Hantverk och Småindustri, I (1946), pp. 19-20. "Behovsprövningen inom folkpensioneringen och närgränsande delar av den svenska socialvården”, Nordisk Försäkringstidskrift, XXVI, 1 (1 January 1946). 
pensions existed at all was, in the abstract, a matter of little concern for these groups that generally relied on their own efforts in such matters. As long as statutory pensions were limited and targeted at the poorest, keeping costs to a minimum, a consensus could be maintained. Once pensions were to be raised significantly, however, means tests deprived the affluent of benefits they had an immediate interest in receiving, even though, in the long run, the additional costs of including even them might (depending on the tax system or other means of financing chosen) come disproportionally from their own pockets. It seems to have been less the sums actually received by making pensions unconditional that interested the classes already provided for than the elimination of psychological disincentives to voluntary provision raised by means tests that was the important consideration. ${ }^{65}$ Unconditional pensions were an immediate, tangible benefit and the disincentive of needs testing sharply felt; eventual tax increases were another matter, largely divorced in systems with substantial state financing from the consideration of social policy itself.

The manual working class had as yet no clearly formulated material interest in universal pension reform. Abolishing means tests still did little for it except insofar as the stigma associated with benefits reserved for the poorest was dispelled. A more enticing goal for blue collar workers was pension parity with their white collar colleagues, although exactly how to achieve this was still a matter of disagreement. Existing occupational pension schemes generally catered to already favored groups of well-paid salaried employees working for large businesses. The effectiveness of private, employer-sponsored arrangements for other groups was doubtful and the possibility of a statutory superannuation scheme of the sort that later would occasion the major political battle of postwar Swedish history was therefore broached early. ${ }^{66}$ However, blue collar workers might also be affected by the disincentives of means testing in the same manner as the more affluent classes. To the extent that occupational schemes took root among them, or that statutory superannuation became a union goal, they too acquired a direct interest in abolishing means tests. Although not yet clearly articulated among the unions, where a concern with stigma prompted their support for the unconditional alternative, such considerations

${ }^{65}$ The Conservatives did not object to the extra taxes abolishing means tests would lead to because those adversely affected in this sense would be compensated by the extra pension benefits eventually received. Since the money, in this calculation, was the same in either case, the advantage of eliminating need as a condition of benefit must have been the psychological spur to savings and work thereby provided. RA, Holmstedts Samling, 2, "Några synpunkter på inkomst - och behovsprövning inom socialvården".

${ }^{66}$ Möller had to intervene to persuade the unions to put aside plans for legislative treatment of superannuation plans until his pension reform had been resolved. LO Archives, Stockholm, Landssekretariatet, minutes, 2 January 1945. 
permitted the Socialists' shift of position on the issue. Party backbenchers, led by Möller, voted down important members of the executive, setting the SAP on a new social policy course guided less by conceptions from the heroic, blue-collared golden age of the 'thirties and more willing to draw the consequences of an incipient coincidence of workers' interests with those of the better-off.

The self-employed who lived in cheaper rural areas, primarily small farmers, foresters and others who often switched between independent and dependent status seasonally, had a mixed interest in pension reform. If the choice were between tax-financed arrangements and the sort of contributory superannuation plans beginning to circulate among the unions, then clearly the former was preferable. Contributory arrangements were of little interest to the poorest independents with neither the income nor the employers to help finance benefits. Conversely, rural employers had no desire to pay contributions for their employees and none to lessen the role of taxes in social policy. Tax-financed measures had traditionally been the demand of Scandinavian farmers, and there was no reason to change now. ${ }^{67}$ Abolishing means tests helped whatever rural inhabitants might have been hampered by them, while not hurting anyone else.

There were ambiguities to the situation, however. The stigma of means testing seems to have affected urban classes more than rural ones in Sweden (unlike the case in Denmark) and rural groups helped themselves unabashedly to targeted benefits. The proportion of those receiving needsbased pension supplements in rural municipalities was twice that of urban areas - a result only partially attributable to migration to the cities and the ageing of the population that remained.$^{68}$ If significant, this might provide an explanation for the disappointment expressed by rural representatives when pension reform was treated in the upper house. These saw the reform as a gain primarily for civil servants and well-placed wage earners with occupational pensions who were now to receive both statutory and private benefits, while those social groups, small independents especially, who had to make do by themselves were disadvantaged. ${ }^{69}$ If rural inhabitants had already taken advantage of targeted benefits, the virtues of eliminating

${ }^{67}$ See my "The Scandinavian Origins of the Social Interpretation of the Welfare State", Comparative Studies in Society and History, forthcoming.

${ }^{68}$ When the issue was brought up in the Social Welfare Committee, Eriksson wondered aloud whether rural authorities dealt with applications for supplementation by the same standards used in the cities. Karl Johan Höjer defended the honor of rural groups, insisting that they had understood, in a way urban residents had not yet accepted, that all pension benefits, the means-tested ones as well, were the citizen's moral and legal right. RA, 1185/1, "Promemoria angående folkpensionering", 25 September 1940; Tilläggspromemoria till P.M. den 25 Sept. 1940; SVK, minutes, 23 October 1940, 28 February 1939, Dahlström.

${ }^{69}$ Riksdagens Protokoll, FK 1946:25, 19 June 1946, pp. 98-100. 
conditions of need would appear less striking to them.

While universalist pension reform took the form of a feast with something for every appetite, bringing all to the table, the bill still had to be paid. Significant state participation made it possible to divorce financing from social legislation itself. At some point, however, the economic realities of these and other reforms had to be faced. Perhaps because any increases in their burdens would likely take the form of new taxes, rather than simply an increase of old ones, farmers were among the first to appreciate the connection between social and tax policy. ${ }^{70}$ For other groups, the process of recognition took longer. While the bourgeois parties had promised reductions of wartime tax levels, the Socialist program emphasized the cost of social reform and the priority of lowering tax burdens for the poor first that ruled out such a course. A tax commission, chaired by Wigforss and dominated by Social Democrats came to similar conclusions.

When the government followed its recommendations, the reaction was widespread and distempered. ${ }^{71}$ The tax issue, gambit of a debate almost as intense as that over superannuation a decade later, was the other side of the apparent unanimity that smoothed the path of pension reform. Disputes that might otherwise have raged over pensions themselves, but which were undercut by their innocuous nature, were displaced to the tax arena where the real burdens had to be apportioned.

The aura that still surrounds the introduction of universalist, egalitarian measures of social policy in Britain and Scandinavia in the wake of the Second World War is misleading. Supposedly born of a wartime spirit of equality and justice and implemented by Socialist governments, postwar reforms haven often been regarded as a turning point in the history of social policy. Including all citizens - the high and the humble, the well-off and the down-and-out - regardless of social class in the same measures on the same

70 Already in the parliamentary treatment of the pension bill, affluent agrarians worried that the lenient tax treatment they enjoyed in common with their colleagues elsewhere in Europe would be a casualty of the new reforms. Proposals for a property tax were currently under examination in committee, a land owner in the upper house noted. Was it not cynical, he wished to know, to increase taxes for those who attempted to save in order to raise the funds required to give well-off wage earners the benefit of both statutory and private measures. Riksdagens Protokoll, FK 1946:25, 19 June 1946, pp. 106-08.

${ }^{71}$ Nils Elvander, Svensk skattepolitik, 1945-1970: En studie i partiers och organisationers funktion (Stockholm, 1972), pp. 26-66. "That pensions were not conditional on means tests was largely the work of the Conservatives, M. Skoglund and A. Hagård. This was just and right, but also expensive. A worried Conservative asked me if it was true that even Wallenberg would get a pension. 'Absolutely,' I answered. 'He may need one if this tax policy continues."' Ivar Anderson, Fràn det nära förflutna: Människor och händelser 1940-1955 (Stockholm, 1969), p. 197. This is a Swedish joke. 
terms seemed an act of progress, enlightenment and social solidarity of a kind rare in the development of the welfare state. However, while attractive, perhaps inspiring, such a view has few other qualities, least of all accuracy, to recommend it. Far from being the result of demands advanced by the Left or the working class, universalist reform represented the adjustment of social policy to reflect the interests of the middle classes not to be excluded from measures that were growing steadily more generous.

The main issue was whether even the affluent members of each social category should receive benefits. The disadvantages of this course were immediate and obvious: why waste scarce resources on those with no need? The advantages were nebulous and long-term: the better-off might be moved by more fervent sentiments of social responsibility when included in the same arrangements as the poor, the stigma of targeted measures would be softened. So it seemed from the perspective of those groups traditionally the object of social policy. From that of the formerly self-reliant groups, things were different. A strong or even more pressing motive for giving benefits to all was that those who were now to be favored with statutory generosity were not blind to what universalism promised them. Swedish Conservatives took the initiative behind universalist pension reform because it was their constituents who stood to gain most from apportioning the state's generosity without regard to need. Socialists at first opposed such a squandering of scarce resources. Granting rights equally was one thing, distributing benefits equally was another. But gradually, the Left too was persuaded to add its approval. Distributing benefits to all was a popular issue and even the unions favored universalist measures for their ability to lessen the stigma of statutory relief. A struggle within the party between old and new guards was fought over the orientation of its social policy attitude and, more generally, the focus of its political concern. The traditional self-image as the defender of the inherently oppressed gave way to a preoccupation with the needs of new groups that were not among the worst-off and with those of the party's traditional constituency as it too partook of postwar prosperity.

Disputes over universalism and solidarity laid bare the tension between justice and efficiency in a world of limited resources. By becoming universalist, social policy was expunged of the taint of poor relief, alms, charity, and dependence and became a right to which each citizen had a claim. Universalizing social policy meant legitimating solidarity by giving the affluent a share of what had earlier been the poor's. Creating such a right required using funds that could have helped the neediest, but it was hoped that the very existence of such a middle-class claim to statutory benevolence would free up more resources than were otherwise available. ${ }^{72}$

72 This logic is clearly mapped out in Anna Hedborg and Rudolf Meidner, Folkhemsmodellen (n.p., 1984), pp. 184-87. 
The needy might, in the long run, gain from this initial misapplication of monies that eventually allowed a more generous estimate of what was available for social redistribution. Such was the theory of the solidaristic Social Democratic welfare state. In political reality, this was not the case. Universalism was prompted by the short-run interests of those classes that stood to lose by being excluded from statutory benefit and that wished to reap the advantages of both their own efforts and the state's. Only in retrospect has Social Democratic whiggery been able to appropriate these reforms for its own purposes. 